\title{
Electro-optic properties of double-type emission of organic electroluminescence device
}

\author{
Helzhynskyy I., Kutsiy S. and Albota S. \\ Lviv Polytechnic National University, 12 S. Bandera Street, 79013 Lviv, Ukraine \\ stepankutsiy@gmail.com
}

Received: 18.01 .2021

\begin{abstract}
We study electroluminescence and impedance properties of a double-type white organic light-emitting device (WOLED) based on phosphorescent and thermally activated delayed fluorescence emissions in a single heterostructure. Current-voltage characteristics of the WOLED and impedance spectroscopy data are obtained for the layered and composite-layer devices. These results demonstrate that a combination of layer-based and composite-based technologies in a single heterostructure improves both the efficiency and the stability of WOLED heterostructures. Light-emission performance of the WOLED is also studied. The device reveals very good electroluminescence properties and colour coordinates as a white light source. Its maximal brightness is larger than $10^{4} \mathrm{~cd} / \mathrm{m}^{2}$ and the maximal external quantum efficiency is larger than $12 \%$.
\end{abstract}

Keywords: organic light-emitting devices, exciplex, impedance spectroscopy, negative capacitance

UDC: 621.38

\section{Introduction}

Further commercialization of white organic light-emitting devices (WOLEDs) as elements of displays is largely hindered by a relatively low power efficiency of organic light-emitting devices. It is known to be due to low efficiency of the blue fluorescent material, which is now widely used as a constituent of WOLEDs [1-3]. Phosphorescent organo-inorganic complexes, which are included into the structure of WOLED as functional layers and allow engagement of triplet excitons in the radiation process [3], improve significantly the energy efficiency of WOLEDs. Then involving blue phosphorescent emitters in the WOLED technology enables one to obtain light-emitting devices with the external quantum efficiency above $20 \%$ [4]. The emission of WOLEDs is a result of total electroluminescence at either two (blue-orange or blue-yellow) or three colours, which are superpositions of blue, green and red. Optimization of WOLEDs has been carried out basing on novel structural and technological solutions. Nonetheless, there still remain some problems such as the energy efficiency and the quality of white-colour saturation of radiation. The same refers to optimization of electron and hole injection, improvement of transport properties of current carriers and improvement of efficiency of exciton generation and recombination in WOLED-based emitters.

Of a particular importance is achieving a balanced emission of each of the emitters (usually blue, green and red or blue and orange). It has recently been found that the energy and the quantum electroluminescence yield are fundamentally affected by triplet excitons participating in the process of thermally activated delayed fluorescence in organic donor-acceptor exciplex complexes [5, 6]. The authors of the recent works $[7,8]$ have reported on implementation of some 
technological approaches and design of device architecture, which have a positive impact on the efficiency and the lifetime of the devices. Combining these techniques can provide a white colour ranging from 'cold' to 'warm'. Additional ultra-thin functional layers in the devices have been used to reduce energy barriers and luminescence quenching [7, 8].

In the present study, we adopt a strategy of forming WOLED structures, which is based on mixing phosphorescent and exciplex thermally activated delayed fluorescence emissions. The aim is to provide highly efficient and stable electroluminescence, with saturated white radiation. In addition, we study comprehensively the mechanisms of current transmission in the light-emitting heterostructures based on organic semiconductors and conduct ac electrical measurements. They allow for determining simultaneously both the resistance and the capacitance of appropriate electric circuits.

\section{Experimental methods}

Given the fact that exciplex radiation is characterized by a 'wide' band, which allows formation of highly efficient WOLEDs, we used 4"-tris[phenyl(m-tolyl)amino] triphenylamine (m-MTDATA) $[6,7]$ as a donor component of exciplex structure. The acceptor component was given by a material based on an ambipolar donor-acceptor molecule (diphenyl sulfone) as an acceptor, and xanthene as a donor fragment of the molecule P6 [8].

A WOLED structure was formed with a method of thermo-vacuum application of organic semiconductor layers and metal electrodes on a pre-cleaned substrate of glass coated with indium tin oxide (ITO). This was performed in a vacuum unit UVN-3M of carousel type with the residual pressure $10^{-5}$ Torr. The structure was formed using gradual deposition of blue and orange components.

The spectral maximum for the thermo-vacuum film exciplex structure P6:m-MTDATA corresponds to the wavelength $524 \mathrm{~nm}$. The reason for spectral expansion observed in case of exciplex is a lack of spectral constraint according to the Franck-Condon principle, because there is no quantization of oscillatory states for the uncoupled ground electronic state which participates in the formation of exciplex [8].

Light-emitting layer of the phosphorescent constituent consisted of two components: a matrix of dicarbazolyl-3,5-benzene $(\mathrm{mCP})$ and a guest phosphorescent (bis(4,6-difluorophenylpyridinato-N,C2) picolinartoiridium, or FIrpic) material used as a blue emitter in the WOLED structure [9]. $m \mathrm{CP}$ was used as a host material, since it had higher triplet energy than that of FIrpic [10].

An ultrathin film of tris(phenyl pyrazole)iridium $(\operatorname{Ir}(\mathrm{ppz}) 3)$ acts in the WOLED structure as an electron-exciton blocking layer due to a high energy of triplets (3.1 eV) [11]. It actually separates the high- and low-energy constituents of white radiation. Note that a phosphorescent composite mixture based on the matrix component $m \mathrm{CP}$ and guest FIrpic were obtained while applying simultaneously two crucibles according to a method presented in Ref. [12]. A CuI film served as an injection hole layer [7]. As hole and electron transport layers in the light-emitting heterostructure, we used an m-MTDATA film and a 1,3,5-tris(n-phenylbenzimidizol-2yl)benzene (TPBI) film, which acted as an electron-transport layer and provided electron injection from $\mathrm{Ca}$ Al cathode to light-emitting layer. The thicknesses of our films were controlled using a quartz resonator. Metal anodes of Ca:Al-based films were applied to the heterostructure in a VUP-5M vacuum unit. 
Pressurization was performed in a nitrogen cabinet in an inert atmosphere. Epoxy-based photopolymer adhesive and protective glasses were used for encapsulation of the WOLED. Glue was applied to peripheral part of the structure, including contact pads of electrodes, and a protective glass was securely fixed on top.

Impedance studies were conducted to analyze generation-recombination processes and interfacial current transmission occurring in our organic light-emitting heterostructure [13, 14]. To find volumetric and interface characteristics of the layered and composite constituents of the heterostructure, we performed impedance studies in the frequency range $10-10^{6} \mathrm{~Hz}$ at constant bias voltages in the range 0-3.0 V. This involved a measuring device "AUTOLAB" (Eco Chemie) and FRA-2 and GPES software. Using a graphical-analytical method and ZView 2.3 software (Scribner Associates), we analyzed the frequency dependences of resistances $Z^{\prime}$ and $Z^{\prime \prime}$. The appropriate error did not exceed $6 \%$.

\section{Results and discussion}

A scheme of energy diagram obtained for our heterostructure ITO/CuI $(7 \mathrm{~nm}) / m \operatorname{MTDATA}(20 \mathrm{~nm})) /$ $\operatorname{Ir}(\mathrm{ppz}) 3(10 \mathrm{~nm}) / m-\mathrm{MTDATA}(30 \mathrm{~nm}) / \mathrm{P6} /(30 \mathrm{~nm}) / \operatorname{Ir}(\mathrm{ppz}) 3(4 \mathrm{~nm}) / m \mathrm{CP}: \operatorname{Frpic}(40 \mathrm{~nm}, 10 \%) \operatorname{TPBi}(30 \mathrm{~nm})$ $/ \mathrm{Ca}: \mathrm{Al}$ is shown in Fig. 1. The electroluminescence spectra measured for $\mathrm{ITO} / \mathrm{CuI} /$ mMTDATA/Ir(ppz)3/m-MTDATA/P6/Ir(ppz)3/mCP:FIrpic/TPBi/Ca:Al are shown in Fig. 2a. They are characterized by two bands of intense radiation.

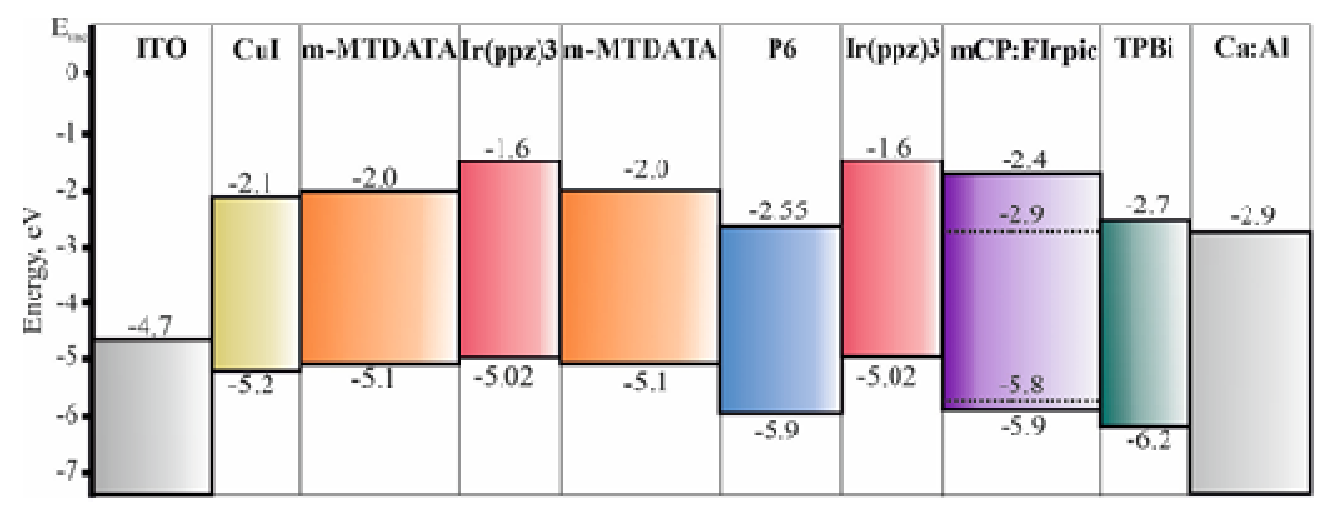

Fig. 1. Schematic energy diagram of our WOLED structure.

The first broad low-energy band of intense radiation located in the region $520-650 \mathrm{~nm}$ is due to the exciplex radiation of $m$-MTDATA/P6 [8]. The second (high-energy) band with the maximum at approximately $470 \mathrm{~nm}$ originates from the electroluminescence of FIrpic (Fig. 2b). The latter is wider, which is due to allowed vibronic transitions [15]. It can be noted that the $m$ MTDATA layer in the WOLED structure exclusively provides exciplex-forming and holetransport functions, which is confirmed by the absence of short-wavelength bands ( $420 \mathrm{~nm})$ typical for the $m$-MTDATA emission [16] (Fig. 2b).

As seen from Fig. 3a, the voltage of inclusion of the organic heterostructure is equal to $V_{\text {in }}=5.2 \mathrm{~V}$, the maximal brightness is larger than $10000 \mathrm{~cd} / \mathrm{m}^{2}$, and the maximal external quantum efficiency exceeds $12 \%$. The $\operatorname{CIE}(x, y)$ coordinates for our WOLED structure ITO/CuI $/ m$ MTDATA/Ir (ppz)3/m-MTDATA/P6/Ir(ppz)3/mCP:FIrpic/TPBi/Ca:Al are equal to $(0.38,0.4)$. They are located in the white zone (see Fig. 2c). In addition, when the current density increases up to $150 \mathrm{~mA} / \mathrm{cm}^{2}$ (Fig. 3b), the electroluminescence spectrum does not change, which indicates good stability of our WOLED.

Ukr. J. Phys. Opt. 2021, Volume 22, Issue 1 

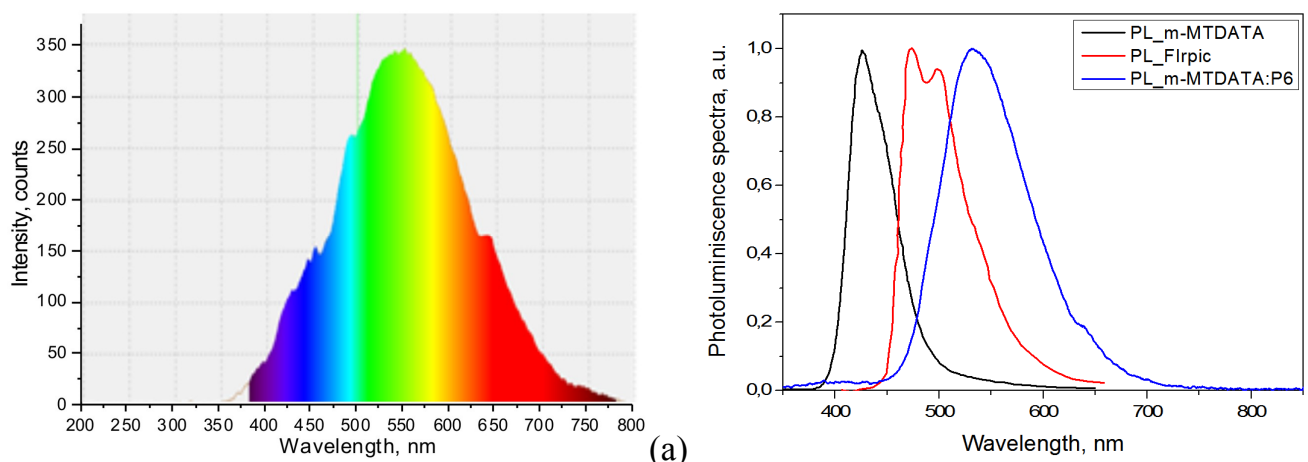

(a)

(b)

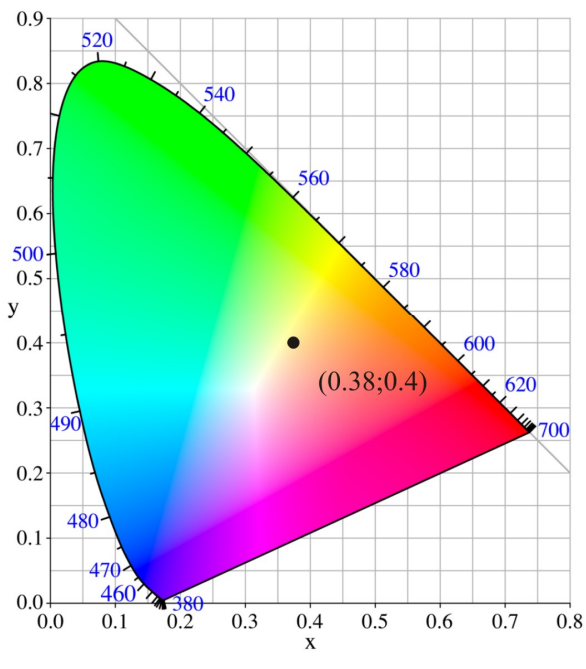

(c)

Fig. 2. Normalized spectrum of electroluminescence for the WOLED structure ITO/Cul/mMTDATA/Ir(ppz)3/mMTDATA/P6/Ir(ppz)3/mCP:Flrpic/TPBi/Ca:Al (a), photoluminescence spectra for $m$-MTDATA, Flrpic and $m$-MTDATA/P6 (b), and chromaticity coordinates CIE1931 with the corresponding values obtained for our WOLED (c).

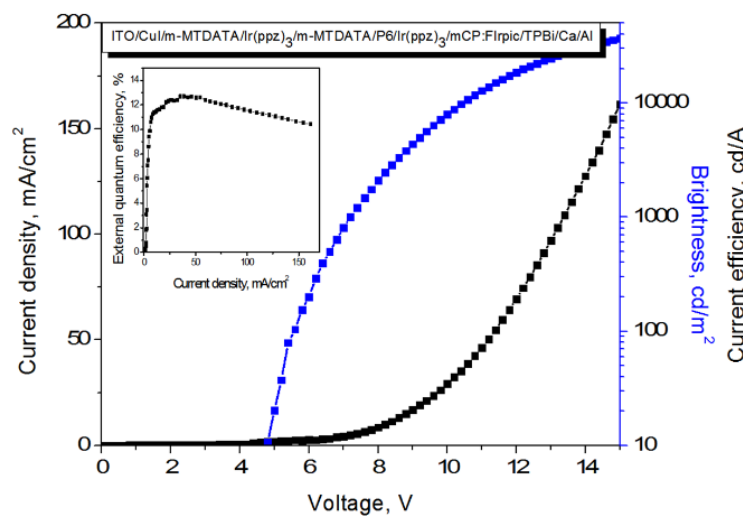

(a)

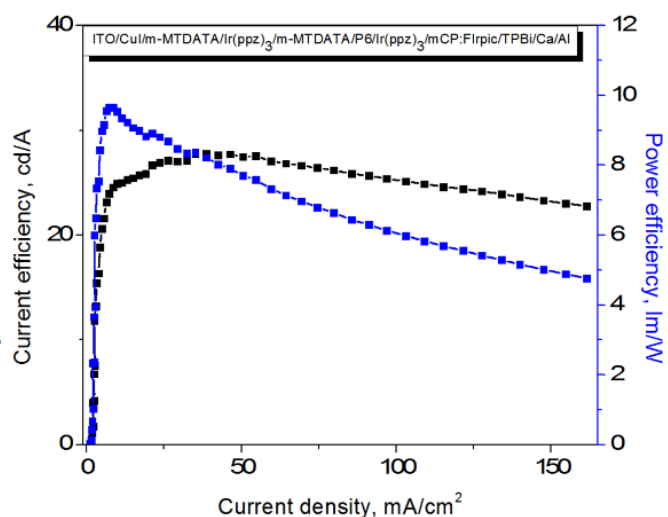

(b)

Fig. 3. Dependences of current density and brightness on the voltage (a), and dependences of current efficiency and power efficiency on the current density (b), as obtained for our WOLED structure. Insert in panel (a) shows dependence of external quantum efficiency on the current density.

Note that the next technological operation used while manufacturing the organic WOLED matrix is passivation of the WOLED structure. Its necessity is explained by the need in insulating the structure from moisture and oxygen on its surface. 


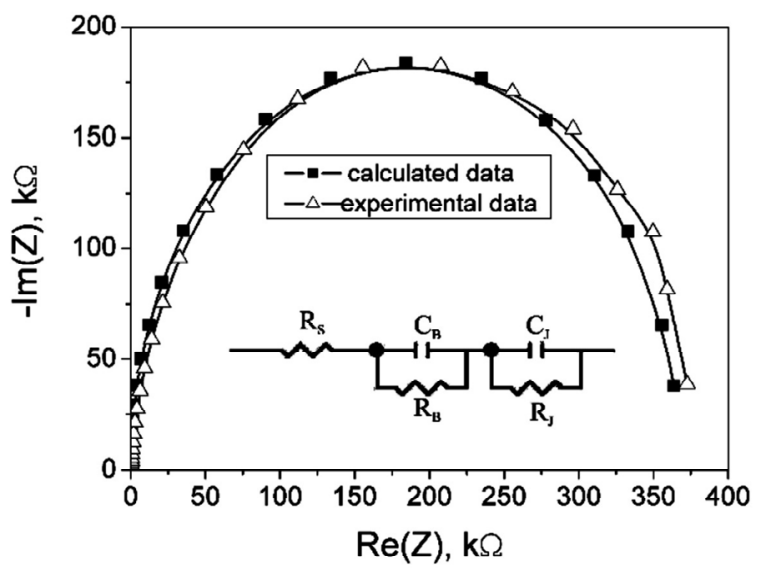

Fig. 4. Experimental and calculated dependences $\operatorname{Im}(Z)$ versus $\operatorname{Re}(Z)$ for the heterojunction ITO/mCP:Flrpic/Ca/Al at the direct displacement 3.0 V. The insert shows equivalent heterojunction scheme.

Fig. 4 displays relationships of the real and imaginary parts of the complex impedance $Z$ obtained for our heterostructure ITO/mCP:FIrpic/Ca/Al in the frequency range from $10 \mathrm{~Hz}$ to $1 \mathrm{MHz}$ at the direct displacement 3.0 V. As seen from Fig. 4, the impedance dependence has a shape of semicircle. This enables one to simulate the heterojunction using an equivalent Schottkydiode circuit, which consists of two series-connected RC-links and a series of resistance $R_{\mathrm{S}}$ (see insert in Fig. 4). This characterizes the volumetric parameters of the heterostructure $\left(R_{\mathrm{B}}\right.$ and $\left.C_{\mathrm{B}}\right)$ and the barrier parameters $\left(R_{\mathrm{J}}\right.$ and $\left.C_{\mathrm{J}}\right)$.

Calculations of the equivalent circuit yield the following parameters: the resistance of ITO and $\mathrm{Ca} / \mathrm{Al}$ contact $R_{\mathrm{S}}=100.27 \Omega$, the barrier resistance $R_{\mathrm{J}}=402 \mathrm{k} \Omega$, the bulk resistance $R_{\mathrm{B}}=148 \Omega$, the bulk capacitance $C_{\mathrm{B}}=2.23 \mathrm{nF}$, and the barrier capacitance $C_{\mathrm{J}}=8.64 \mathrm{nF}$. The resistance value $R_{\mathrm{S}}$ is caused by the presence of quasi-ohmic composite/ITO contact. In the lowfrequency area, the resistance of the heterostructure is significant. It is mainly determined by the total real constituent of the resistance $R_{\mathrm{B}}+R_{\mathrm{J}}$ [17]. As the frequency increases, the capacitances $C_{\mathrm{J}}$ and $C_{\mathrm{B}}$ begin to contribute more and more into the process of current flow. It is known from Refs. $[18,19]$ that, when modelling the impedance dependences of diode structures with equivalent circuits (like that displayed in the insert of Fig. 4), one has to observe a low-frequency maximum. It features a potential barrier between the composite and the metal. In the highfrequency area, the dominant role in the current passage is played by the $R_{\mathrm{B}} C_{\mathrm{B}}$-link and we observe a maximum $\left(\operatorname{Re}\left(Z_{\mathrm{B}}\right)=\operatorname{Im}\left(Z_{\mathrm{B}}\right)\right)$ [19]. This makes it possible to determine the value of the volumetric capacitance $C_{\mathrm{B}}=2,23 \mathrm{nF}$ at the resistance $R_{\mathrm{B}}=148 \Omega$. Low conductivity of the composite layer is caused by a high-resistance component of the organo-metallic complex and a frequency dependence of the electrical conductivity of organic semiconductors within the composite [20]. The absence of the induced component in the equivalent circuit, which is typical for the most of OLED structures, is explained by low energy barriers of the guest-host materials (e.g., $m$ CP:FIrpic), with minimal accumulation of charge carriers on the interface.

The ITO/m-MTDATA/P6/Ca/Al heterostructure has been formed to study the exciplex constituent. Fig. 5 shows the dependences of the real and imaginary parts of the complex impedance for the heterostructure of exciplex constituent in the frequency range from $10 \mathrm{~Hz}$ to $1 \mathrm{MHz}$, at the direct displacement $3.0 \mathrm{~V}$. The dependence has a shape of two weakly expressed semicircles. The latter fact allows one to simulate the heterojunction with an equivalent-circuit diode structure. It also 
consists of two series-connected $R_{\mathrm{C}}$-links and a series of resistance $R_{\mathrm{S}}$ (see insert in Fig. 5). It characterizes the volumetric parameters of the heterostructure $\left(R_{\mathrm{B}}\right.$ and $\left.C_{\mathrm{B}}\right)$ and the barrier parameters $\left(R_{\mathrm{J}}\right.$ and $\left.C_{\mathrm{J}}\right)$, which occur at the boundary of two organic semiconductors [21].

In the above equivalent scheme, the exciplex layer (see the insert in Fig. 5) is represented by the capacitance of the transition $C_{\mathrm{J}}$ and the resistance of the transition $R_{\mathrm{J}}$. There is a volume area between the exciplex layer and the electrodes (ITO and $\mathrm{Ca} / \mathrm{Al}$ ), which we represent by the capacitance $C_{\mathrm{B}}$ and the resistance $R_{\mathrm{B}}$ in the equivalent circuit. The resistance of the $R C$ corresponds to the total resistance of the ITO and $\mathrm{Ca} / \mathrm{Al}$ contacts.

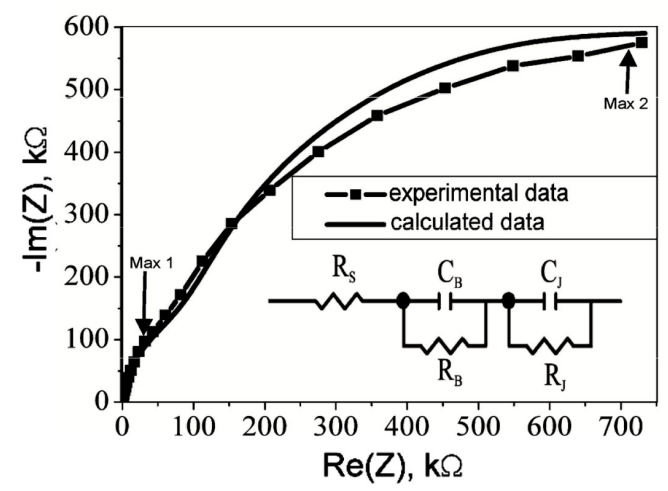

Fig. 5. Experimental and calculated dependences of $\operatorname{Im}(Z)$ on $\operatorname{Re}(Z)$ for the ITO/m-MTDATA/P6/Ca/AI heterojunction at a direct displacement of $3.0 \mathrm{~V}$. Equivalent heterojunction scheme is displayed in the insert.

The resistance of the exciplex heterostructure becomes significant in the low-frequency area. It is mainly determined by the total real constituent of the resistances $R_{\mathrm{B}}+R_{\mathrm{J}}$ [22], while the capacitance of the junction makes a significant contribution into current flow. The low-frequency maximum (see Fig. 5) corresponds to the $R C$-link (see the insert in Fig. 5). It features the heterojunction barrier. It is worthwhile that, under the condition of equality of the imaginary and real constituents of the impedance, it is easy to determine the junction capacitance [21, 22]. In our case, we obtain the junction capacitance $C_{\mathrm{J}}=92 \mathrm{nF}$ at $R_{\mathrm{J}}=720 \mathrm{k} \Omega$. As the frequency increases, the capacitance of the $C_{\mathrm{J}}$ junction limits the current flow through the heterojunction. Then the influence of the $R C$-link responsible for the heterojunction can be neglected. The $R_{\mathrm{B}} C_{\mathrm{B}}$-link plays a dominant role in the current passage. When the ratio is equal to $\left.R_{\mathrm{B}}=1 /\left(2 \pi f B C_{\mathrm{B}}\right)\right)$, the second maximum is observed (see Fig. 5). Accordingly, the value of the volumetric capacitance becomes $C_{\mathrm{B}}=38 \mathrm{nF}$ at the resistance $R_{\mathrm{B}}=101 \mathrm{k} \Omega$. Ideally, with a further frequency increase, the resistance of the heterostructure should be equal to zero. However, due to high energy barrier at the exciplex interface ( $m$-MTDATA/P6), the resistance takes only the value $882 \Omega$, which corresponds to the $R_{\mathrm{C}}$ value.

\section{Conclusion}

In this work we have presented the strategy of formation of the WOLED, which is based on double-type emission in the organic functional layer. We have formed the appropriate device when combining the layer-based and composite-based technologies in a single heterostructure. The lightemission performance of the OLED structure has been investigated. Our results have indicated very good electroluminescence properties for our structure as a white phosphorescent light source. In particular, the maximal brightness is larger than $10000 \mathrm{~cd} / \mathrm{m}^{2}$ and the maximal external quantum efficiency exceeds $12 \%$. The WOLED structure investigated by us is characterized by a sufficient roll-off stability along all current-density directions. 
The impedance-spectroscopy studies of our layered structures based upon both experiments and simulations have unambiguously pointed to the fact that there is neither energy barrier at the host-quest interface nor high-energy barrier at the exciplex interfaces, which is needed for exciplex formation.

\section{Acknowledgment}

The authors would like to acknowledge financial support of the present study from the UkrainianLithuanian R\&D project M-57-2020-2021 and the Ministry of Education and Science of Ukraine (the Project No. 0119U100259).

\section{References}

1. Wook Songa, Mei Menga, You Hyun, Kima Chang-Bum, Moona Chul, Gyu Jhuna Sang, Youn Leeb, Richard Wood and Woo-Young Kim, 2012. High efficient and color stable WOLED using double white emissive layer. J. Lumin. 132: 2122-2125.

2. Sanghyuk Park, Ji Eon Kwon, Se Hun Kim, Jangwon Seo, Kyeongwoon Chung, Sun-Young Park, Du-Jeon Jang, Begoña Milián Medina, Johannes Gierschner, and Soo Young Park, 2009. A white-light-emitting molecule: frustrated energy transfer between constituent emitting centers. J. Amer. Chem. Soc. 131: 14043-14049.

3. Li C, Xu Y, Liu Y, Ren Z, Ma Y and Yan S, 2019. Highly efficient white-emitting thermally activated delayed fluorescence polymers: synthesis, non-doped white OLEDs and electroluminescent mechanism. Nano Energy. 65: 104057.

4. Hung W Y, Fang G-C, Lin S-W, Cheng S-H, Wong K-T, Kuo T-Y and Chou P T, 2014. The first tandem, all-exciplex-based WOLED. Sci. Rep. 4: 5161.

5. Nakagawa T, Ku S-Y, Wong K-T and Adachi C, 2012. Electroluminescence based on thermally activated delayed fluorescence generated by a spirobifluorene donor-acceptor structure. Chem. Commun. 48: 9580-9582.

6. Xie W, Zhao Y, Li C and Liu S, 2005. High-efficiency electrophosphorescent white organic light-emitting devices with a double- doped emissive layer. Semicond. Sci. Techn. 20: 1245.

7. Hotra Z, Stakhira P, Cherpak V, Volynyuk D, Voznyak L, Gorbulyk V and Tsizh B, 2012. Effect of thickness of $\mathrm{CuI}$ hole injection layer on properties of organic light emitting diodes. Photon. Lett. Poland. 4: 35-37.

8. Tan X, Volyniuk D, Matulaitis T, Keruckas J, Ivaniuk Kh, Helzhynskyy I, Stakhira P and Grazulevicius J V, 2020. High triplet energy materials for efficient exciplex-based and fullTADF-based white OLEDs. Dyes and Pigments. 177: 108259.

9. Etienne Baranoff and Basile F E Curchod, 2015. FIrpic: archetypal blue phosphorescent emitter for electroluminescence. Dalton Trans. 44: 8318-8329.

10. Jong-Kwan, Bin Nam-Sung Cho and Jong-In Hong, 2012. New host material for highperformancblue phosphorescent organic electroluminescent devices. Adv. Mater. 24: 2911-2915.

11. Nam Eun Jeong, Kim Jun Ho, Kim Bong-Ok, Kim Sung Min, Park No Gill, Kim Young Sik, Kim Young Kwan and Ha Yunkyoung, 2004. A synthesis and luminescence study of $\operatorname{Ir}(\mathrm{ppz}) 3$ for organic light-emitting devices. Bull. Chem. Soc. Jap. 77: 751-755.

12. Motoyama Takao, Sasabe Hisahiro, Seino Yuki, Takamatsu Jun-ichi and Kido Junji, 2011. An $\alpha$-carboline-containing host material for high-efficiency blue and green phosphorescent OLEDs. Chem. Lett. 40: 306-308.

13. Pfeiffer M, Leo K, Zhou X, Huang J S, Hofmann M, Werner A and Blochwitz-Nimoth J, 2003. Doped organic semiconductors: physics and application in light emitting diodes. Organ. Electron. 4: 89-103.

Ukr. J. Phys. Opt. 2021, Volume 22, Issue 1 
14. Weiying Gao and Antoine Kahn, 2002. Electronic structure and current injection in zinc phthalocyanine doped with tetrafluorotetracyanoquinodimethane: interface versus bulk effects. Organ. Electron. 3: 53-63.

15. Qing Zhang, Bo Wang, Jianghong Tan, Guangyuan Mu, Wei Yi, Xialei Lv, Shaoqing Zhuang, Wei Liu and Lei Wang, 2017. Optimized electron-transport material based on m-terphenyldiphenylphosphine oxide with the harmonious compatibility of high ET and electron mobility for highly efficient OLEDs. J. Mater. Chem. C. 5: 8516-8526.

16. Grybauskaite-Kaminskiene G, Ivaniuk Kh, Bagdziunas G, Turyk P, Stakhira P, Baryshnikov G, Volyniuk D, Cherpak V, Minaev B, Hotra Z, Agren H and Grazulevicius J V, 2018. Contribution of TADF and exciplex emission for efficient "warm-white" OLEDs. J. Mater. Chem. C. 6: 1543-1550.

17. Lungenschmied C, Dennler G, Neugebauer H, Sariciftci S N, Glatthaar M, Meyer T and Meyer A, 2007. Flexible, long-lived, large-area, organic solar cells. Sol. Energy Mater. Sol. Cells. 91: 379-384.

18. Szmytkowski J, 2007. The photocurrent quantum efficiency dependence on the applied voltage in organic solar cells. Semicond. Sci. Technol. 22: 1329-1331.

19. Krebs F C, 2007. Low band gap polymer materials for organic solar cells solar energy. Mater. Sol. Cells. 91: 953-961.

20. Niggemann M, Zimmermann B, Haschke J, Glatthaar M and Gombert A, 2008. Organic solar cell modules for specific applications - from energy autonomous systems to large area photovoltaics. Thin Solid Films. 516: 7181-7187.

21. Toccoli T, Boschetti A, Corradi C, Guerini L, Mazzola M and Iannotta S, 2003. Codeposition of phthalocyanines and fullerene by SuMBE: characterization and prototype devices. Synth. Metals. 138: 3-7.

22. Brousse B, Ratier B and Moliton A, 2004. Vapor deposited solar cells based on heterojunction or interpenetrating networks of zinc phthalocyanine and C60. Thin Solid Films. 451-452: 81-85.

Helzhynskyy I., Kutsiy S. and Albota S. 2021 Electro-optic properties of double-type emission of organic electroluminescence device. Ukr.J.Phys.Opt. 22: 53 - 60. doi: 10.3116/16091833/22/1/53/2021

Анотація. Вивчено електролюмінесцениію та імпедансні властивості білого органічного світловипромінювального пристрою (БОСП) подвійного типу на основі фосфоресцентної та термічно активованої флуоресцентної емісій із затримкою, об'єднаних в єдиній гетероструктурі. Одержано вольт-амперні характеристики БОСП та дані імпедансної спектроскопії для шаруватих та композитно-шарових приладів. Ці результати демонструють, щзо комбінування технологій на основі шаруватості та композитності в єдиній гетероструктурі поліпшує і ефективність, і стабільність гетероструктур БОСП. Вивчено ефективність світлового випромінювання органічного світлодіода. Пристрій виявляє дуже хороші властивості електролюмінесцениії та кольорові координати як джерело білого світла. Його максимальна яскравість перевищує $10^{4} \kappa \partial / \mathrm{m}^{2}$, а максимальна зовнішня квантова ефективність вищза за 12\%. 